\title{
Digestive Organs, Caecal Metabolites and Fermentation Pattern in Coypus (Myocastor coypus) and Rabbits (Oryctolagus cuniculus)
}

\author{
M. MAROUNEK ${ }^{1}{ }^{2}$, M. SKŘIVAN ${ }^{2}$, P. BŘEZINA ${ }^{3}$, I. HOZA $^{3}$ \\ ${ }^{1}$ Institute of Animal Physiology and Genetics, Czech Academy of Sciences, \\ Prague, Czech Republic \\ ${ }^{2}$ Research Institute of Animal Production, Prague, Czech Republic \\ ${ }^{3}$ Faculty of Technology, Tomáš Bata University in Zlín, Zlín, Czech Republic
}

Received September 22, 2004

Accepted March 3, 2005

\begin{abstract}
Marounek M., M.Skřivan, P. Březina, I. Hoza: Digestive Organs, Caecal Metabolites and Fermentation Pattern in Coypus (Myocastor coypus) and Rabbits (Oryctolagus cuniculus). Acta Vet. Brno, 2005, 74: 3-7.

Six coypus and six rabbits fed the same granulated feed ad libitum were slaughtered, digestive organs with their contents weighed and digesta samples analyzed. The caecum was the largest digestive organ in both animal species. Its weight averaged $170 \mathrm{~g}$ in coypus and $157 \mathrm{~g}$ in rabbits (4.1 and $5.5 \%$ of the total body weight, respectively). In rabbits, the weight of stomach was greater and that of the small intestine smaller than in coypus ( 135 and 89 vs 85 and $111 \mathrm{~g}$ ). Gastric acidity, caecal and colonic dry matter concentration were significantly higher in rabbits. Total volatile fatty acids (VFA) and ammonia concentrations in the caecal contents of coypus and rabbits were similar (100.1 and $23.3 \mu \mathrm{mol} / \mathrm{g}$ in coypus, and 103.7 and $25.5 \mu \mathrm{mol} / \mathrm{g}$ in rabbits, respectively). Molar percentages of acetate and propionate, however, were significantly higher and percentage of butyrate lower in caecal VFA of coypus than in rabbits $(P<0.002)$. The caecal contents were diluted with buffer and incubated anaerobically to determine the caecal fermentation pattern. Caecal microorganisms of coypus produced more propionate and methane, and less butyrate and valerate than caecal microbes of rabbits $(P<0.05)$. Thus, different major hydrogen sinks exist in the coypu and rabbit caecum. In conclusion, there are both differences and similarities in parameters of digestion in both animal species. Caecal fermentation pattern differed more than other parameters investigated.
\end{abstract}

Coypu, rabbit, weight, digestive tract, digestion, caecum, fermentation

Coypus (Myocastor coypus) and rabbits (Oryctolagus cuniculus) are medium-sized herbivore animals with similar morphological features of the digestive tract. In both species the caecum is the primary site of digesta retention and microbial fermentation. Both coypus and rabbits practise caecotrophy, i.e. produce two types of faeces, soft and hard, and reingest soft ones. Soft faeces (fermented caecal material) are rich in nutrients, whereas hard faeces are basically a refuse. Comparative nutritional trials with coypus and rabbits are scarce, as well as with other non-ruminant herbivores. Hullár et al. (1992ab) found that coypus fibre requirement and the significance of caecotrophy were lower, probably due to continuous availability of low-fibre parts of aquatic plants in the coypu's natural environment. A high-fibre feedstuff (lucerne) was digested less efficiently in coypus than in rabbits, but in case of feedstuffs low in fibre (maize, wheat), or containing the fibre in an easily digestible form (wheat bran) no difference in digestibility coefficients was observed. Caecal microorganisms of coypus produced more propionate and methane, and less butyrate than caecal microorganisms of rabbits (Marounek et al. 1999).

This study has been aimed at extending our knowledge on comparative digestive physiology of herbivore animals. Thus, weights of digestive organs, acidity and dry matter (DM) concentration of their contents, and concentration of caecal metabolites were determined in coypus and rabbits fed the same diet ad libitum, as well as the stoichiometry of fermentation in cultures of caecal contents. 


\section{Materials and Methods}

Six broiler rabbits, Hyplus breed, and six coypus were fed ad libitum a commercial granulated feed containing lucerne meal, wheat bran, sunflower meal, oats, barley, sugarbeet pulp, and soyabean meal as the main ingredients (Table 1). Rabbits and coypus were slaughtered at the age of 3 and 6 months, respectively, between 06:30 and 08:00 h. After slaughtering, the stomach, small intestine, caecum and colon were isolated by ligating organs with a string to prevent movement of the digesta. Digestive organs were weighed and their contents squeezed out into beakers. In all samples, the $\mathrm{pH}$ was measured and $\mathrm{DM}$ concentration determined by drying at $105^{\circ} \mathrm{C}$. The caecal contents $(10 \mathrm{~g})$ were added to $30 \mathrm{ml}$ of water or Burroughs buffer (Burroughs et al. 1950) with yeast extract $\left(1 \mathrm{~g} \cdot \mathrm{l}^{-1}\right)$ and urea $\left(0.5 \mathrm{~g} \cdot 1^{-1}\right)$. To stop the fermentation in former samples, $\mathrm{HgCl}_{2}$ was added immediately. The latter samples were incubated with or without a substrate $(0.6 \mathrm{~g}$ of wheat bran $)$ in $100 \mathrm{ml}$ serum bottles at $39^{\circ} \mathrm{C}$ for $24 \mathrm{~h}$. The bottles were thoroughly flushed with $\mathrm{CO}_{2}$ and hermetically closed with rubber stoppers. Sodium sulphide was added to the incubation fluid at $0.5 \mathrm{~g} \cdot \mathrm{l}^{-1}$ as a reducing agent. The $\mathrm{pH}$ (above 7 initially) fell by $0.7-0.9$ in the course of the incubation.

Table 1. Ingredients and determined chemical composition of coypu and rabbit diet

\begin{tabular}{|l|l|l|c|}
\hline \multicolumn{2}{|l|}{ Ingredients (\%) } & Nutrients $\left(\mathrm{g} \cdot \mathrm{kg}^{-1}\right)$ & \\
\hline Alfalfa meal & 30 & Dry matter & 914 \\
\hline Wheat bran & 22.5 & Crude fibre & 194 \\
\hline Sunflower meal & 17 & Crude protein & 175 \\
\hline Oat & 9 & Fat & 26 \\
\hline Barley & 8 & Ash & \\
\hline Sugarbeet pulp & 6 & & \\
\hline Soyabean meal & 3 & & \\
\hline Rapeseed oil & 1.5 & & \\
\hline Vitamin supplement & 1 & & \\
\hline Limestone & 1 & & \\
\hline Dicalciumphosphate & 0.5 & & \\
\hline Salt & 0.5 & & \\
\hline
\end{tabular}

Contents of fibre and fat in the feed were determined employing instruments Fibertec 2010 and Soxtec 1043 from Tecator AB (Sweden). Total nitrogen $(\mathrm{N})$ in the feed and caecal contents was determined using the Kjeltec Auto 1030 Analyser from the same firm. Drying at $105^{\circ} \mathrm{C}$ and ashing at $550{ }^{\circ} \mathrm{C}$ were used to determine DM and ash concentration in the diet, respectively. Total volatile fatty acids (VFA) were estimated by titration, after steam distillation. Their molar composition was determined on a gas chromatograph using a column of the Chromosorb WAW with $15 \%$ SP $1220 / 1 \% \mathrm{H}_{3} \mathrm{PO}_{4}$ (Supelco) at $140{ }^{\circ} \mathrm{C}$. Samples of the headspace gas were taken at the end of the incubation and analysed on the same column. At the same time, the manometric pressure in the incubation vessels was measured. Lactic acid was assayed by the microdiffusion method (Conway 1957). Ammonia was determined colorimetrically with Nessler reagent (after prior separation from interfering compounds by microdiffusion in Conway units) in samples diluted with water and clarified by centrifugation ( $8000 \mathrm{~g}$ for $20 \mathrm{~min}$ ).

Metabolic hydrogen balance was calculated according to Demeyer (1991), except that also the caproate production was taken into account (Marounek et al. 2000):

2 Hreleased $=2 \mathrm{~A}+\mathrm{P}+4 \mathrm{~B}+3 \mathrm{~V}+6 \mathrm{C}$

2 Haccepted $=4 \mathrm{M}+2 \mathrm{P}+2 \mathrm{~B}+4 \mathrm{~V}+4 \mathrm{C}$

2 Hrecovery $=(2$ Haccepted $/ 2$ Hreleased $) .100 \%$

where A, P, B, V, C and M represent molar production of acetate, propionate, butyrate, valerate, caproate and methane, respectively. Such calculation compares the amounts of metabolic hydrogen produced and recovered in reduced end products. The significance of differences was evaluated by the $t$-test.

\section{Results and Discussion}

At the time of slaughter, the average body weight of coypus was $4.13 \pm 0.43 \mathrm{~kg}$ and that of rabbits $2.87 \pm 0.36 \mathrm{~kg}$. The caecum was the heaviest digestive organ in both animal species (Table 2). Both stomach weight and relative proportion of stomach weight from the body weight were greater in rabbits than in coypus. The gastric $\mathrm{pH}$ was significantly higher and dry matter concentration in the hindgut lower in coypus than in rabbits. Total VFA, total $\mathrm{N}$ per $1 \mathrm{~g}$ of DM and ammonia concentration in the caecal contents of coypus and rabbits were similar (Table 3). In rabbits, caecal VFA concentration exceeded the upper value of this trait reported by García et al. (2002) by $3.9 \mathrm{mmol} / \mathrm{l}$. Ammonia N represented 4.81 and 
$3.93 \%$ of the total $\mathrm{N}$ in the caecal contents of coypus and rabbits, respectively. Molar percentages of acetate and propionate were significantly higher and percentage of butyrate lower in caecal VFA of coypus than in rabbits. The caecal contents of coypus contained more lactate $(P<0.002)$. Caecal microorganisms of coypus produced significantly more propionate and methane, and less butyrate and valerate than microorganisms of rabbits (Table 4).

Table 2. Weights of digestive organs of six coypus and six rabbits, digesta dry matter concentration and $\mathrm{pH}$

\begin{tabular}{|l|c|c|c|}
\hline & Weight $(\mathrm{g})$ & Dry matter $(\%)$ & $\mathrm{pH}$ \\
\hline $\begin{array}{l}\text { Coypus } \\
\text { Stomach }\end{array}$ & $85.1 \pm 14.3^{*}(2.1 \%)$ & $17.6 \pm 1.8$ & $3.80 \pm 0.65^{*}$ \\
\hline Small intestine & $110.6 \pm 13.9^{*}(2.5 \%)$ & $13.5 \pm 1.3$ & $6.98 \pm 0.12$ \\
\hline Caecum & $169.8 \pm 17.8(4.1 \%)$ & $17.9 \pm 0.6^{*}$ & $6.10 \pm 0.28$ \\
\hline Colon & $115.8 \pm 20.2^{*}(2.8 \%)$ & $19.4 \pm 1.7^{*}$ & $6.16 \pm 0.25$ \\
\hline $\begin{array}{l}\text { Rabbits } \\
\text { Stomach }\end{array}$ & $135.3 \pm 15.8(4.7 \%)$ & $19.0 \pm 3.0$ & $2.39 \pm 0.31$ \\
\hline Small intestine & $89.2 \pm 15.9(3.1 \%)$ & $11.4 \pm 2.9$ & $6.96 \pm 0.11$ \\
\hline Caecum & $156.7 \pm 18.4(5.5 \%)$ & $24.1 \pm 1.9$ & $5.81 \pm 0.28$ \\
\hline Colon & $68.6 \pm 13.5(2.4 \%)$ & $24.6 \pm 2.2$ & $6.10 \pm 0.25$ \\
\hline
\end{tabular}

Means \pm SD

Values in parentheses are percentages of organ weight from animal weight

* Significantly different from a corresponding value in rabbits $(P<0.05)$

Table 3. Caecal metabolites in six coypus and six rabbits

\begin{tabular}{|l|c|c|}
\hline & Coypus & Rabbits \\
\hline Total VFA $^{\mathrm{a}}$ & $100.1 \pm 25.2$ & $103.7 \pm 15.8$ \\
\hline Acetate $^{\mathrm{b}}$ & $73.9 \pm 4.1^{*}$ & $62.8 \pm 4.1$ \\
\hline Propionate $^{\mathrm{b}}$ & $18.6 \pm 2.2^{*}$ & $10.1 \pm 4.1$ \\
\hline Butyrate $^{\mathrm{b}}$ & $7.4 \pm 2.0^{*}$ & $22.7 \pm 3.7$ \\
\hline Other VFA $^{\mathrm{b}}$ & $0.1 \pm 0.1^{*}$ & $4.4 \pm 1.3$ \\
\hline Lactate $^{\mathrm{a}}$ & $2.6 \pm 0.3^{*}$ & $1.1 \pm 0.1$ \\
\hline Total N $^{\mathrm{c}}$ & $6.78 \pm 0.48^{*}$ & $9.09 \pm 1.24$ \\
\hline Total N $^{\mathrm{d}}$ & $37.9 \pm 2.8$ & $37.7 \pm 2.6$ \\
\hline Ammonia N & $23.3 \pm 9.2$ & $25.5 \pm 8.0$ \\
\hline
\end{tabular}

Means $\pm \mathrm{SD},{ }^{\mathrm{a}} \mu \mathrm{mol} / \mathrm{g},{ }^{\mathrm{b}} \mathrm{mol} . \%,{ }^{\mathrm{c}} \mathrm{mg} / \mathrm{g},{ }^{\mathrm{d}} \mathrm{mg} / \mathrm{g} \mathrm{DM}$

*Significantly different from a corresponding value in rabbits $(P<0.002)$

Small amount of caproate was produced in caecal cultures of rabbits but not in those of coypus. Hydrogen recovery in latter cultures was significantly higher. Methane represented 28.7 and $12.8 \%(\mathrm{v} / \mathrm{v})$ of the headspace gas in substrate-supplied cultures of the coypu and rabbit caecal contents, respectively. In substrate-free cultures the total production of VFA, gas and methane were decreased $(P<0.05)$. This was accompanied with a non-significant increase of $2 \mathrm{H}$ recovery and marginal shifts in molar proportions of individual VFA. The butyrate molar percentages, however, were significantly lower in rabbit caecal cultures without the substrate. Methane represented 51.2 and $14.8 \%$ of the headspace gas in substrate-free cultures of the coypu and rabbit caecal contents, respectively.

Coypus and rabbits belong to different orders (Rodentia and Lagomorpha, respectively), though related. They originate from different geographical regions with different ecological conditions. Hullár et al. (1992ab) showed that despite similar features of the coypu and rabbit digestive tract, rabbit digestibility coefficients cannot be 
used in the coypu nutrition, especially in case of high-fibre feedstuffs. In this study coypus consumed feed primarily formulated for rabbits without apparent problems. A knowledge on digestive physiology of coypus is poor. Considering the large caecum, one could suppose a great similarity between coypus and rabbits, which are the beststudied caecum fermenters. This assumption was not verified in this study. A noteworthy difference in the digestive morphology of coypus and rabbits was a smaller size of the stomach in former animals, which may be the consequence of a limited extent of the caecotrophy. Low DM concentration in the coypu caecal and colonic contents probably reflects little need for the conservation of water. Significantly lower DM concentration in the coypu caecal contents was observed also in our previous study (Marounek et al. 1999).

Table 4. Production of volatile fatty acids, methane, gas and hydrogen recovery in cultures of caecal contents of coypus and rabbits

\begin{tabular}{|l|c|c|c|}
\hline & Substrate $^{\mathrm{a}}$ & Coypus & Rabbits \\
\hline Total VFA $^{\mathrm{b}}$ & + & $97.6 \pm 17.2$ & $61.2 \pm 8.6$ \\
\hline Acetate $^{\mathrm{c}}$ & + & $64.1 \pm 2.8$ & $9.7 \pm 1.0$ \\
\hline Propionate $^{\mathrm{c}}$ & + & $21.3 \pm 1.9^{*}$ & $22.3 \pm 1.6$ \\
\hline Butyrate $^{\mathrm{c}}$ & + & $11.1 \pm 0.9^{*}$ & $2.6 \pm 0.7$ \\
\hline Valerate $^{\mathrm{c}}$ & + & $0.7 \pm 0.1^{*}$ & $1.6 \pm 0.6$ \\
\hline Caproate $^{\mathrm{c}}$ & + & 0 & $3.5 \pm 2.0$ \\
\hline Isoacids $^{\mathrm{c}}$ & + & $2.8 \pm 0.5$ & $8.7 \pm 2.4$ \\
\hline Methane $^{\mathrm{b}}$ & + & $17.3 \pm 2.7^{*}$ & $1.64 \pm 0.14$ \\
\hline Gas $^{\mathrm{d}}$ & + & $1.46 \pm 0.37$ & $52.2 \pm 7.8$ \\
\hline 2H recovery & $70.7 \pm 6.9^{*}$ & $36.8 \pm 8.7$ \\
\hline & + & & $61.1 \pm 1.0$ \\
\hline Total VFA $^{\mathrm{b}}$ & - & $50.5 \pm 10.6$ & $10.7 \pm 1.1$ \\
\hline Acetate $^{\mathrm{c}}$ & - & $66.0 \pm 2.2^{*}$ & $18.5 \pm 1.1$ \\
\hline Propionate $^{\mathrm{c}}$ & - & $19.5 \pm 1.3^{*}$ & $3.1 \pm 1.1$ \\
\hline Butyrate $^{\mathrm{c}}$ & - & $9.7 \pm 0.8^{*}$ & $1.2 \pm 0.4$ \\
\hline Valerate $^{\mathrm{c}}$ & - & $1.5 \pm 0.7^{*}$ & $5.4 \pm 0.8$ \\
\hline Caproate $^{\mathrm{c}}$ & - & $0^{*}$ & $4.9 \pm 1.3$ \\
\hline Isoacids $^{\mathrm{c}}$ & - & $3.3 \pm 2.2$ & $0.80 \pm 0.19$ \\
\hline Methane $^{\mathrm{b}}$ & - & $0.51 \pm 0.23$ & $57.7 \pm 12.3$ \\
\hline Gas $^{\mathrm{d}}$ & - & $77.0 \pm 6.7^{*}$ & \\
\hline 2 H recovery $^{\mathrm{e}}$ & - & & \\
\hline
\end{tabular}

Means of 4 cultures $\pm \mathrm{SD},{ }^{\mathrm{a}}$ Wheat bran $(0.6 \mathrm{~g} / 40 \mathrm{ml}),{ }^{\mathrm{b}} \mu \mathrm{mol} / \mathrm{g},{ }^{\mathrm{c}} \mathrm{mol} . \%,{ }^{\mathrm{d}} \mathrm{ml} / \mathrm{ml}, \quad \mathrm{e} \%$

*Significantly different from a corresponding value in rabbits $(P<0.05)$

The caecal fermentation pattern in coypus and rabbits differed. High production of propionate and methane, and, consequently, high $2 \mathrm{H}$ recoveries in the coypu caecal cultures indicate that different major hydrogen sinks (methanogenesis $v s$ synthesis of acetate from $\mathrm{CO}_{2}$ and $\mathrm{H}_{2}$ ) exist in the caeca of coypus and rabbits. This may be caused by the composition of nutrients leaving the small intestine and/or by different microorganisms colonizing the caeca. One mmol of $\mathrm{CH}_{4}$ was produced per 5.64 and 9.33 mmols of VFA in the coypu and rabbit caecal cultures with substrate, respectively. Corresponding values in cultures without a substrate were 4.68 and 7.51 . The lack of fermentable substrate thus increased the relative importance of caecal methanogenesis, as observed also by Piattoni et al. (1997) in fasting rabbits. In conclusion, caecal fermentation pattern differed in coypus and rabbits more than other parameters examined in this study or reported by other authors. 


\section{Hmotnosti orgánů trávicí soustavy, metabolity obsahu slepých střev a fermentační stechiometrie u nutrií (Myocastor coypus) a králíků (Oryctolagus cuniculus)}

Šest nutrií a šest králíků bylo krmeno stejným granulovaným krmivem ad libitum. Po porážce byly váženy orgány trávicí soustavy spolu s obsahem a obsah analyzován. U všech zviŕat byla hmotnost slepého střeva větší než hmotnost žaludku, tenkého stř̌eva či tračníku. V průměru činila $170 \mathrm{~g}$ u nutrií a $157 \mathrm{~g}$ u králíků (4,1 a 5,5\% celkové tělesné hmotnosti). Průměrná hmotnost žaludku byla $135 \mathrm{~g} \mathrm{u}$ králíků a $85 \mathrm{~g}$ u nutrií, hmotnost tenkého střeva 89 g u králíků a 111 g u nutrií. Králíci měli vyšší aciditu obsahu žaludku a vyšší obsah sušiny v zažitině slepého střeva a tračníku. Nálezy koncentrace těkavých mastných kyselin (TMK) a amoniaku byly podobné (100,1 a 23,3 $\mu \mathrm{mol} / \mathrm{g}$ u nutrií, 103,7 a 25,5 $\mu \mathrm{mol} / \mathrm{g} \mathrm{u} \mathrm{králíků)}$. Molární zastoupení TMK bylo ale signifikantně odlišné: acetátu a propionátu vyšší u nutrií, butyrátu vyšší u králíků $(p<0,002)$. Obsahy slepých střev byly zředěny pufrem a inkubovány za anaerobních podmínek. Mikroorganismy slepých střev nutrií produkovaly signifikantně více propionátu a metanu a méně butyrátu a valerátu než mikroorganismy slepých střev králíků $(p<0,05)$. Lze tudíž konstatovat, že s metabolickým vodíkem nakládají rozdílným způsobem. Přestože ve způsobu trávení lze u obou živočišných druhů shledat některé podobnosti, existuje i řada rozdílů, zejména co se týče stechiometrie fermentace $\mathrm{v}$ slepém střevu, které je při trávení rostlinné potravy u nutrií i králíků velmi významné.

\section{Acknowledgement}

This study received financial support from the Ministry of Education, Youth and Sports of the Czech Republic (project OC 848.001 of the programme COST).

\section{References}

BURROUGHS WN, FRANK A, GERLAUGH P, BETHKE RM 1950: Preliminary observations upon factors influencing cellulose digestion by rumen micro-organisms. J Nutr 40: 9-24

CONWAY EJ 1957: Microdiffusion Analysis and Volumetric Error, $4^{\text {th }}$ edition. Crosby Lockwood and Son, London

DEMEYER DI 1991: Quantitative aspects of microbial metabolism in the rumen and hindgut. In: Jouany J-P (ed.) Rumen Microbial Metabolism and Ruminant Digestion. EditINRA, Paris, pp. 217-237

GARCÍA J, GIDENNE T, FALCAO-E-CUNHA C, de BLAS C 2002: Identification of the main factors that influence caecal fermentation traits in growing rabbits. Anim Res 51: 165-173

HULLÁR I, FEKETE S, GIPPERT T 1992a: How do coypu and rabbit digest the same feedstuffs? Scientifur 16: 298-302

HULLÁR I, FEKETE S, GIPPERT T 1992b: Comparison of the rabbit and coypu digestion on the base of digestibility trials. J Appl Rabbit Res 15: 995-1007

MAROUNEK M, BŘEZINA P, BARAN M 2000: Fermentation of carbohydrates and yield of microbial protein in mixed cultures of rabbit caecal microorganisms. Arch Anim Nutr 53: 241-252

MAROUNEK M, SKRIVAN M, SKRIVANOVA V 1999: Caecal fermentation pattern in coypus and rabbits. In: Proceedings of the $5^{\text {th }}$ International Symposium on the Nutrition of Herbivores. San Antonio, TX (USA). CDROM

PIATTONI F, DEMEYER D, MAERTENS L 1997: Fasting effects on in vitro fermentation pattern of rabbit caecal contents. Wld Rabbit Sci 5: 23-26 